Verheul, Susanne: "Z imbabweans are foolishly litigious": exploring the logic of appeals to a politicized legal system / Susanne Verheul. - In: Africa (Edinburgh), 86 (February 2016) 1. S. 78-97, Lit., Lit. Hinw.

Waldorf, Lars: Inhumanity's law: crimes aginst humanity, RtoP and South Sudan / Lars Waldorf. - In: International Politics (Basingstoke), 53 (January 2016) 1. S. 49-66

Zenker, Olaf: South African land restitution, white claimants and the fateful frontier of fomer KwaNdebele / Olaf Zenker. - In: Journal of Southern African Studies (Abingdon), 41 (October 2015) 5. S. 1019-1034, Lit. Hinw.

\title{
ASIEN /ASIA
}

Bader, Julia; Daxecker, Ursula E.: A Chinese resource curse?: The human rights effects of oil export dependence on China versus the United States / Julia Bader ; Ursula Daxecker. - In: Journal of Peace Research (London), 52 (November 2015) 6. S. 774-790, graph.Darst., Tab., Lit. S. 787-790

Budd, Christopher; Ahlawat, Dalbir: Reconsidering the Paracel Islands dispute: an international law perspective / Christopher Budd and Dalbir Ahlawat. - In: Strategic Analysis (Abingdon), 39 (November-December 2015) 6. S. 661-682

Cohen, David; Hyde, Melanie; Van Tuyl, Penelope: A well-reasoned opinion?: Critical analysis of the first case against the alleged senior leaders of the Khmer Grouge (case 002/01) / David Cohen, Melanie Hyde \& Penelope Van Tuyl. With Stephanie Fung. - Honolulu/Haw.: East-West Center, 2015 - VIII, 98S., graph. Darst., Tab. ISBN 978-0-86638-270-0; 978-0-86638-271-7

The future of "rule according to law" in China- In: Asia Policy / National Bureau of Asian Research (Seattle/Wash.), (July 2015) 20. S. 2-44

Glaser, Henning: Constitutional conflict and restatement: the challenge and transformation of the hegemonic basic consent in Thailand / Henning Glaser. - In: Norms, interests, and values: conflict and consent in the constitutional basic order / Henning Glaser (ed.). - Baden-Baden: Nomos, 2015. - (CPG Series of Comparative Constitutional Law, Politics and Governance ; 2). S. 291-343, Lit. S. 341-343, Lit. Hinw. ISBN 978-3-8452-4738-0; 978-3-8487-0432-3

Gresbrand, Klaus: Die Corporate Governance der dokuritsu gyōsei hōjin: eine deutsche Perspektive / Klaus Gresbrand. - In: Zeitschrift für japanisches Recht (Hamburg), 20 (Winter 2015) 40. S. 59-97, Tab., Lit., Lit.-Hinw.

Hamm, Brigitte; Schax, Anne: Human rights due diligence through stakeholder engagement?: The case of a copper-gold mine in the Philippines / Brigitte Hamm ; Anne Schax. - Duisburg: INEF, 2015 - 54S., graph. Darst., Tab., Anh. S. 49-54, Lit. S. 43-47, Lit. -Hinw. - (INEF-Report; $109 / 2015)$

Hwang, Jau-yuan: Divided national identities and constitutional changes: the case of Taiwan / JauYuan Hwang. - In: Norms, interests, and values: conflict and consent in the constitutional basic order / Henning Glaser (ed.). - Baden-Baden: Nomos, 2015. - (CPG Series of Comparative Constitutional Law, Politics and Governance ; 2). S. 181-196, Tab., Lit. S. 196, Lit.Hinw ISBN 978-3-8452-4738-0; 978-3-8487-0432-3 
Jones, Colin P. A.: The influence of Amakudari on the Japanese legal system / Colin P. A. Jones. - In: Zeitschrift für japanisches Recht (Hamburg), 20 (Winter 2015) 40. S. 1-57, Tab., Lit., Lit.-Hinw.

Kokado, Minori: A new phase in the regulation of assisted reproductive technology in Japan / Minori Kokado. - In: Zeitschrift für japanisches Recht (Hamburg), 20 (Winter 2015) 40. S. 211-232, graph. Darst., Tab., Lit., Lit.-Hinw.

Krug, Barbara; Libman, Alexander: Commitment to local autonomy in non-democracies: Russia and China compared / Barbara Krug ; Alexander Libman. - In: Constitutional Political Economy (Dordrecht), 26 (June 2015) 2. S. 221-245, Tab., Lit. S. 240-245

Krumbein, Frédéric: P. C. Chang - the Chinese father of human rights / Fréderic Krumbein. - In: Journal of Human Rights [Philadelphia/Pa.] (Philadelphia/Pa.), 14 (2015) 3. S. 332-352, Tab., Lit. S. 349-351

Low, Choo Chin: Same system, different outcomes: comparing the implementation of dual nationality treaties in East Germany and China / Choo Chin Low. - In: Europe-Asia Studies (Abingdon), 67 (December 2015) 10. S. 1656-1684

Ma, Yide: The role of consultative democracy in a constitutional system and the rule of law in China / Ma Yide. - In: Social Sciences in China (Abingdon), 36 (November 2015) 4. S. 5-23

Machmudi, Yon: The development of political Islam in Indonesia / Yon Machmudi. - In: Norms, interests, and values: conflict and consent in the constitutional basic order / Henning Glaser (ed.). Baden-Baden: Nomos, 2015. - (CPG Series of Comparative Constitutional Law, Politics and Governance ; 2). S. 237-248, Lit. S. 248, Lit. Hinw. ISBN 978-3-8452-4738-0; 978-3-8487-0432-3

McCargo, Duncan: Peopling Thailand's 2015 draft constitution / Duncan McCargo. - In: Contemporary Southeast Asia (Singapore), 37 (December 2015) 3. S. 329-354, Lit.-Hinw. S. 349-354

Nagata, Yohei: Überblick über wichtige zivilrechtliche Entscheidungen des japanischen Obersten Gerichtshofs aus dem Jahre 2013 / Yohei Nagata. - In: Zeitschrift für japanisches Recht (Hamburg), 20 (Winter 2015) 40. S. 257-283, Tab., Lit., Lit.-Hinw.

Nagata, Yohei; Tidten, Dan: Überblick über wichtige zivilrechtliche Entscheidungen des japanischen Obersten Gerichtshofs aus dem Jahre 2012 / Yohei Nagata/ Dan Tidten. - In: Zeitschrift für japanisches Recht (Hamburg), 20 (Winter 2015) 40. S. 233-256, Tab., Lit., Lit. -Hinw.

Nemoto, Hisanori: Grundlagen des zivilrechtlichen Beseitigungs- und Unterlassungsanspruchs in Japan / Hisanori Nemeto. - In: Zeitschrift für japanisches Recht (Hamburg), 20 (Winter 2015) 40. S. 193-209, Lit., Lit.-Hinw.

Nias, Noorjehan Safia; Soman, Zakia: Muslim women's view on Muslim personal law / Noorjehan Safia Nias ; Zakia Soman. - In: Economic and Political Weekly (Mumbai), 50 (December 19, 2015) 51. S. 83-87, Lit., Lit. Hinw.

Pardieck, Andrew M.: Executing contracts in Japan / Andrew M. Pardieck. - In: Zeitschrift für japanisches Recht (Hamburg), 20 (Winter 2015) 40. S. 183-191, Lit., Lit.-Hinw.

Poole, Avery: "The world ist outraged": legitimacy in the making of the ASEAN human rights body / Avery Poole. - In: Contemporary Southeast Asia (Singapore), 37 (December 2015) 3. S. 355-380, Lit.-Hinw. S 374-380 
Primiano, Christopher B.: The impact of international perception on China's approach to human rights / Christopher B. Primiano. - In: East Asia: an International Quarterly (Dordrecht), 32 (December 2015) 4. S. 401-419

Sengupta, Arghya; Kumar, C. Raj: [Appointment of judges] / Arghya Sengupta ; C. Raj Kumar. - In: Economic and Political Weekly (Mumbai), 50 (November 28, 2015) 48. S. 27-34, Lit., Lit. Hinw.

Seymour, James D.; Wong, Patrick Yuk-tung: China and the international human rights covenants / James D. Seymour and Patrick Yuk-tung Wong. - In: Critical Asian Studies (Cedar/Mich.), 47 (December 2015) 4. S. 514-536, Anh. S. 531-536, Lit. S. 529-530, Lit.-Hinw.

Simandjuntak, Deasy: Spectacle of the scaffold?: The politics of death penalty in Indonesia / by Deasy Simandjuntak. - Singapore: ISEAS - Institute of Southeast Asian Studies, 2015 - 8S., Lit. Hinw. - (ISEAS Perspective; 46/2015) ISSN 2335-6677

Simões, Fernando Dias: Law and language in Timor-Leste: bridging the divide / Fernando Dias Simoes. - In: Contemporary Southeast Asia (Singapore), 37 (December 2015) 3. S. 381-405, Li.Hinw. S. 401-405

Strating, Rebecca; Edmondson, Beth: Beyond democratic tolerance: witch killings in Timor-Leste / Rebecca Strating, Beth Edmondson. - In: Journal of Current Southeast Asian Affairs (Hamburg), 34 (2015) 3. S. 37-64, Lit. S. 59-64

Thier, Markus: Japan auf dem Weg vom "Insiderparadies" zu einer effektiven Regulierung des Insiderhandels / Markus Thier. - In: Zeitschrift für japanisches Recht (Hamburg), 20 (Winter 2015) 40. S. 145-181, Tab., Lit., Lit.-Hinw.

Thio, Li-ann: Constitutionalism and religious diversity in Singapore: a via media between principle and pragmatism? / Li-ann Thio. - In: Norms, interests, and values: conflict and consent in the constitutional basic order / Henning Glaser (ed.). - Baden-Baden: Nomos, 2015. - (CPG Series of Comparative Constitutional Law, Politics and Governance ; 2). S. 197-236, Lit. S. 234-236, Lit. Hinw. ISBN 978-3-8452-4738-0; 978-3-8487-0432-3

Ufen, Andreas; Mietzner, Marcus: Political finance regimes in Southeast Asia: introduction / Andreas Ufen und Marcus Mietzner. - In: Critical Asian Studies (Cedar/Mich.), 47 (December 2015) 4. S. 558-563, Lit., Lit.-Hinw.

\section{LATEINAMERIKA / LATIN AMERICA}

Bogdandy, Armin von: Ius Constitutionale Commune en América Latina: Beobachtungen zu einem transformatorischen Ansatz demokratischer Verfassungsstaatlichkeit / Armin von Bogdandy. - In: Zeitschrift für ausländisches öffentliches Recht und Völkerrecht (München), 75 (2015) 2. S. 345-381

Centro de Estudios Legales y Sociales (Buenos Aires): Derechos humanos en Argentina: informe 2015 / Marcela Perelman ... (eds.). Centro de Estudios Legales y Sociales. - Buenos Aires: Siglo XXI, 2015 - 632S., graph. Darst., Tab. ISBN 978-987-629-539-0

Corrales, Javier: The politics of LGBT rights in Latin America and the Caribbean: research agendas / Javier Corrales. - In: Revista Europea de Estudios Latinoamericanos y del Caribe (Amsterdam), (2015) 100. S. 53-62, Lit. S. 61-62 